SECTION 32. Jurisprudence.

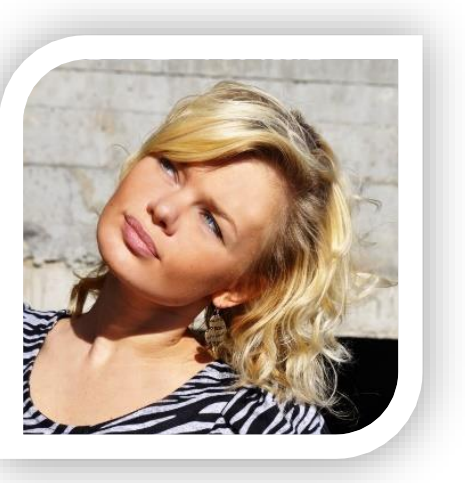

Proshina Christina Yurevna

graduate student

The Russian presidential academy of national economy and public administration.

Volgograd branch

Russia

kristinaproshina@mail.ru

\title{
THE CONSTITUTIONAL LEGAL DUTY IN THE SPHERE OF THE NATURE- RESOURCE RELATIONS: THEORY AND PRACTICE QUESTIONS
}

Abstract: In article the problem of observance of the constitutional duty on preservation of the nature, environment, and also careful attitude to natural riches is considered.

Key words: nature, ecological right, environment, protection of natural resources.

\section{УДК $[001,12+303,2]: 662.76$}

\section{КОНСТИТУЦИОННО - ПРАВОВАЯ ОБЯЗАННОСТЬ В СФЕРЕ ПРИРОДОРЕСУРСНЫХ ОТНОШЕНИЙ: ВОПРОСЫ ТЕОРИИ И ПРАКТИКИ}

Аннотация: $B$ статье рассматривается проблема соблюдения конституционной обязанности по сохранению природы, окружающей среды, а также бережного отношения к природным богатствам.

Ключевые слова: природа, экологическое право, окружающяая среда, охрана природных ресурсов.

Приступая к рассмотрению данной проблемы, будет правильным заметить, что уже в середине XX века приобрели глобальный характер вопросы сохранения окружающей среды. Безусловно, рассматривая развитие инновационной экономики страны, необходимо отметить необходимость модернизации процессов контроля, сохранения и восстановления экологической системы [10 с.14].

Однако, помимо конституционных прав, отраженных, например, в статье 7, 36,41 , а также в статье 42 Конституции РФ [2; 3] установлены и конституционные обязанности, предусмотренные, в частности, статьей 58 Конституции РФ. Указанная статья закрепляет, что «Каждый обязан сохранять природу и окружающую среду, бережно относиться к природным богатствам».

Статью 58 Конституции РФ будет правильно трактовать, как распространяющуюся на граждан РФ, иностранных лиц, а также лиц без гражданства, которые находятся на территории нашей страны [7, с.10].

Безусловно, реализация экологических прав граждан напрямую зависит от выполнения установленных обязанностей как юридических, так и физических лиц.

В данном контексте необходимо указать, что обязанность своим личным трудом оберегать приумножать природные богатства, вести активную деятельность по повышению уровня знаний о природе, экологическую культуру, можно смело отнести не только к правовым, но и к моральным требованиям. 
Так, согласно российскому природоохранному законодательству, граждане обязаны принимать эффективные меры по соблюдению технологического режима и выполнению требований по охране природы, рациональному использованию, воспроизводству природных ресурсов, а также оздоровлению окружающей среды. Хотелось бы заметить, что на сегодняшний день существует ряд федеральных законов, направленных на сохранение и защиту окружающей среды от негативного воздействия, создаваемого современным обществом в процессе своей жизнедеятельности, способных вызывать как деградацию, так и полное уничтожение экосистемы Земли.

На ограничение и контроль над деятельностью человечества в сфере иррационального использования природных богатств, направлены следующие законодательные акты:

- Ф3 «Об охране окружающей среды» в статье 11 закрепляет обязанности граждан сохранять природу и окружающую среду, бережно относится к природе и природным богатствам, а также соблюдать иные требования законодательства;

- Федеральный закон "О внесении изменений и дополнений в Закон Российской Федерации "О недрах", а именно статья 22, закрепляет основные права и обязанности пользователя недр;

- Водный кодекс РФ в статье 39 закрепляет права и обязанности собственников водных объектов, водопользователей при использовании водных объектов;

- Федеральный закон "О животном мире" в статье 40 закрепляет права и обязанности в сфере использования и охране животного мира;

- Федеральный закон "Об охране атмосферного воздуха" в статье 30 закрепляет обязанности граждан и юридических лиц, имеющих стационарные и передвижные источники выбросов вредных (загрязняющих) веществ в атмосферный воздух.

По применению норм вышеприведенных нормативных актов в России складывается интересная правоприменительная практика.

Так, 8 мая и 29 мая 2012 г. в отношении гражданина К. старшим инспектором отдела государственного охотничьего надзора управления по надзору и охране животного мира Министерства природопользования и экологии Рязанской области А. были составлены протоколы о совершении административных правонарушений, ответственность за которые предусмотрена ч. 1 ст. 8.37 КоАП РФ.

26 июня 2012 г. постановлением начальника управления по надзору и охране животного мира Минприроды Рязанской области он был привлечен к административной ответственности по ч. 1 ст. 8.37 КоАП РФ и ему назначено наказание в виде административного штрафа. Соответственно, это говорит о том, что каждое лицо, которое в той или иной степени нарушает действующее законодательство, обязательно должно быть привлечено к юридической ответственности [1].

Помимо административной ответственности, за совершение преступлений в сфере охраны окружающей среды возможна также уголовная, гражданско-правовая и дисциплинарная ответственность [13, С.130-142].

В данном контексте отметим важную роль Постановления Пленума Верховного суда РФ, разъяснившего судам необходимость обратить внимание на то, что установленное статьей 42 Конституции РФ право каждого на благоприятную окружающую среду, а также предусмотренные статьей 58 Конституции РФ обязанности обеспечиваются путем правильного применения законодательства об ответственности за нарушение в области охраны окружающей среды и 
природопользования [8]. Постановление Пленума Верховного суда РФ является важным разъяснительным документом, применение которого в процессе судебного заседания позволит полноценно, точно и всестороннее изучить конкретное дело, и, соответственно, вынести по нему единственно верное решение.

Возвращаясь к рассмотрению статьи 58 Конституции РФ, уделим внимание ее субъектному составу, на который возлагается ряд экологических обязанностей.

Например, В.П. Басик к таким субъектам относит только граждан РФ, иностранных граждан и лиц без гражданства. По мнению данного автора, предусмотренная вышеуказанной статьей обязанность выступает составляющей любого правового статуса указанных лиц. [4, с. 9]

В свою очередь, по мнению А.В. Фокина, экологические обязанности человека и гражданина можно определить как вид и меру должного и необходимого поведения приведенных лиц в целях обеспечения благоприятных условий окружающей среды [11, с. 10].

С.А. Боголюбов в своей статье "Обязанности природопользования" говорит о применении конституционных норм, предполагаемых исполнение экологических обязанностей непосредственно предпринимателями и должностными лицами [5].

Согласно рассмотренным позициям, будет верным заметить, что субъектами экологических правоотношений, и, в частности, регулируемых статьей 58 Конституции РФ, необходимо считать как физических лиц (к которым относятся граждане РФ, иностранные граждане и лица без гражданства), так и юридических лиц. Соответственно, полагаю, необходимо более четко конкретизировать в статье 58 Конституции субъектов ответственности за совершение экологических правонарушений.

Рассмотрев теоретический аспект рассматриваемой тематики, обратим внимание на ряд судебных актов, посвященных реализации положений статьи 58 Конституции РФ. Наиболее интересным из них является Постановление Конституционного Суда Российской Федерации от 14.05.2009 г. №8-П, которым установлено, что обязанность, предусмотренная статьей 58 Конституции РФ по сохранению природы и окружающей среды, а также бережного отношения к богатствам природы, выступает частью обеспечительного механизма реализации конституционного права каждого на благоприятную окружающую среду [9].

С этим трудно не согласиться. Действительно, если каждый гражданин нашей страны хотя бы немного внимания уделит реализации данной нормы, и будет бережно относится к природе, сохраняя ее и окружающую среду, то общество сможет побороть имеющийся сегодня эколого-правовой нигилизм. Для реализации данной нормы на практике необходимо осуществить разработку федеральных и региональных целевых экологических программ (например, по озеленению дворов), в которых заложить механизм финансирования экологических мероприятий для каждого региона и муниципалитета. Это и будет верный путь к уменьшению количества правонарушений и преступлений, ежегодно совершаемых в экологической сфере.

Также, на наш взгляд, интересен анализ ответственности за нарушение экологического законодательства США и Республики Казахстан.

Административно-правовые санкции, применяемые органами государственного экологического контроля США, являются эффективным средством соблюдения государственной экологической дисциплины и обеспечения надлежащего качества окружающей среды. Основными видами административноправовых санкций являются предписания о прекращении или запрещении той или иной противоправной деятельности, обязательные указания об устранении 
допущенных нарушений и проведении мероприятий по предотвращению подобного рода нарушений в дальнейшем (administrative compliance order) и штраф (fine).

Приведем ряд законодательных примеров: согласно Закону "О чистоте вод" ЕРА имеет право взыскать с нарушителя штраф в размере до 10 тыс. долл. за каждое нарушение, но не свыше 25 тыс. долл. В тех случаях, когда нарушение имеет длящийся характер, взыскивается штраф в размере до 10 тыс. долл. за каждый день в течение всего срока нарушения, но не свыше 125 тыс. долл. Законом "О чистоте атмосферного воздуха" предусмотрено взыскание штрафа в размере до 25 тыс. долл. с изготовителя, продавца и поставщика новых автомашин или автомобильных моторов, если выброс выхлопных газов выпускаемой или реализуемой ими продукции выше установленных стандартом нормативов [6, с. 95].

В свою очередь, законодательство Республики Казахстан содержит следующие условия ответственности: Глава 19 КоАП РК содержит порядка 70 статей в области охраны окружающей среды и использования природных ресурсов. Наряду с этим, статья 123 КоАП РК в главе 13 «Административные правонарушения, посягающие на собственность», предусматривает ответственность за выборочную отработку участков месторождения, приведшую к ухудшению качества оставшихся запасов, необоснованным сверхпроектным и сверхнормативным потерям полезных ископаемых, а также за несоблюдение проектных решений по отработке участков месторождения, повлекшее причинение вреда окружающей среде.

Существующие штрафные санкции, установленные административным законодательством, имеют своей целью охрану прав, свобод и законных интересов человека и гражданина, здоровья, санитарно-эпидемиологического благополучия населения, окружающей среды, а также предупреждение их совершения. Но по нашему мнению, они все же не могут способствовать восстановлению нарушенного экологического баланса. Нарушения экологического законодательства должны влечь применение мер наказания, адекватных их опасности, а также вреду, причиняемому окружающей природной среде и обществу [12].

На основании всего сказанного можно придти к выводу, что экологические обязанности должны сопровождаться ответственностью и обязанностями государства. Рассмотренный в настоящей статье субъективный аспект позволил конкретизовать лиц, ответственных за нарушение экологического законодательства.

\section{Список литературы}

1. Апелляционное определение Рязанского областного суда от 20.11.2013 № 332454 // СПС «Консультант плюс». Дата обращения 23.02.2014.

2. Анисимов А.П. Право человека и гражданина на благоприятную окружающую природную среду (конституционно-правовые аспекты): автореф. дис. ... канд. юрид. наук. - Волгоград, 1997. 30 с.

3. Анисимов А.П., Мелихов А.И. Конституционно-правовое регулирование права частной собственности на земельные участки: монография. - Волгоград: типография ООО «Мастер», 2009. - $216 \mathrm{c}$.

4. Басик В.П. Обязанности граждан Российской Федерации и иностранцев. М.: Изд-во Моск. ун-та, 2003. 320 с.

5. Боголюбов С.А. Обязанности природопользователей // Право и экономика. 2001. - № 8 / http://www.lawmix.ru/comm/5892 (дата обращения 23.02.2014)

6. Брославский Л.И. Административно-правовые санкции за нарушение экологического законодательства США// Журнал российского права. 2010. № 12. С.94100. 
7. Дмитриев Ю.А. Конституция РФ: Научно-практический комментарий. М., 2007. 532c.

8. Постановление Пленума Верховного Суда РФ от 18.10.2012 N 21 "О применении судами законодательства об ответственности за нарушения в области охраны окружающей среды и природопользования" // СПС «Гарант», дата обращения 23.02.2014.

9. Постановление Конституционного Суда РФ от 14.05.2009 N 8-П "По делу о проверке конституционности положения подпункта "б" пункта 4 Постановления Правительства Российской Федерации "Об утверждении Порядка определения платы и ее предельных размеров за загрязнение окружающей природной среды, размещение отходов, другие виды вредного воздействия" в связи с запросом Верховного суда Республики Татарстан" // СПС «Гарант», дата обращения 22.02.2014.

10. Седов А.И. Конституционные и правовые основы формирования экологического права в Российской Федерации // Российская юстиция. - 2012. - № 1. - C.14-15.

11. Фокин А. В. Экологические права и обязанности человека и гражданина: теоретико-правовой аспект: дис. ... канд. юрид. наук. - Волгоград, 2006. 179с.

12. Хабарова Н.А. Правовые проблемы ответственности за нарушение экологического законодательства Республики Казахстан. 2012/ Электронный источник: http://kze.docdat.com/docs/66/index-487046.html

13.Экологическое право. Курс лекций: учебное пособие / под ред. А.П. Анисимова. - М.: «Приор-издат», 2003. 272 с. 